Article

\title{
A Study on the Influence of Conformity Behaviors, Perceived Risks, and Customer Engagement on Group Buying Intention: A Case Study of Community E-Commerce Platforms
}

\author{
Chueh-Chu Ou ${ }^{1}$, Kuan-Liang Chen ${ }^{1}$, Wei-Kuo Tseng ${ }^{2, *}$ and Ya-Yun Lin ${ }^{1}$ \\ 1 Department of Marketing and Logistics Management, Ling Tung University, Taichung 40851, Taiwan; \\ daphneou2001@teamail.ltu.edu.tw (C.-C.O.); kl@mail.ltu.edu.tw (K.-L.C.); juim3864@gmail.com (Y.-Y.L.) \\ 2 Department of Business Management, National Taichung University of Science and Technology, \\ Taichung 40851, Taiwan \\ * Correspondence: weikuot@nutc.edu.tw
}

check for updates

Citation: Ou, C.-C.; Chen, K.-L.;

Tseng, W.-K.; Lin, Y.-Y. A Study on the Influence of Conformity Behaviors, Perceived Risks, and Customer Engagement on Group Buying Intention: A Case Study of Community E-Commerce Platforms. Sustainability 2022, 14, 1941. https:// doi.org/10.3390/su14041941

Academic Editor: Lester Johnson

Received: 30 December 2021

Accepted: 1 February 2022

Published: 9 February 2022

Publisher's Note: MDPI stays neutral with regard to jurisdictional claims in published maps and institutional affiliations.

Copyright: (C) 2022 by the authors. Licensee MDPI, Basel, Switzerland. This article is an open access article distributed under the terms and conditions of the Creative Commons Attribution (CC BY) license (https:// creativecommons.org/licenses/by/ $4.0 /)$.

\begin{abstract}
This study mainly probed into the factors influencing consumers' OGB intention on community e-commerce platforms, built models that included facets of conformity behaviors, perceived risks, customer engagement, and OGB intention, and focused on whether there is a mediating effect on customer engagement and an interference effect on perceived risks. The subjects of this study were consumers with OGB experience on community e-commerce platforms. The results show that conformity behaviors have a significant positive impact on customer engagement and OGB intention; thus, when customers have insufficient information or relevant knowledge of OGB, the comments or recommendations of their relatives and friends would influence their engagement and OGB intention. Moreover, this study found that customer engagement has a complete mediating effect, which indicates that conformity behaviors can influence OGB intention through customer engagement. In addition, this study found that perceived risks have an interference effect, meaning that when consumers sense high risks, the OGB intention is weakened through customer engagement. This shows that in the OGB organizations of the community e-commerce platforms, it is recommended that more attention be paid to customer engagement; it is also a topic worthy of discussion in practical business applications.
\end{abstract}

Keywords: community e-commerce platform; perceived risk; conformity behavior; customer engagement; OGB intention

\section{Introduction}

How big is the e-commerce market? In 2019, Statista (2019) found that global retail ecommerce sales reached USD 3.53 trillion and were expected to grow to USD 6.54 trillion by 2022, which shows that the potential for developing the online shopping market is infinite. As network applications become more life-oriented, the "online group buying (OGB)" community business is becoming an important part of e-commerce. There are three business models that often appear in the OGB market. The first is mainly a business-initiated transaction model where the seller provides a kind of products that can be purchased at a discount when the consumer purchases in bulk within a limited time; the second is an independent third party-initiated transaction model in which a platform provides products for OGB where consumers make a large number of purchases from sellers to obtain the lowest discount; the third is a consumer-initiated transaction model, which is different from the business-initiated transaction and the independent third-party initiated transaction models as the promoter of this model is also a consumer who calls on friends and relatives to buy the products together and ask the seller to provide a discounted price.

Most previous studies explored the OGB decision-making process of the first B2C e-commerce OGB model [1,2] or the second C2B e-commerce OGB model [3], including 
information collection, decision-making, repurchase willingness, and other issues. However, few scholars have studied the OGB model of $\mathrm{C} 2 \mathrm{C}$ community platforms to explore consumer behaviors. C2C community OGB platforms are LINE shopping communities that are mainly composed of the promoter's family members, friends, colleagues, and classmates (natural relationships) unlike the $\mathrm{B} 2 \mathrm{C}$ and $\mathrm{C} 2 \mathrm{~B}$ model where the customers do not know each other. That is to say, the community C2C OGB relationship is a relationship of close and physical interactions between each other, meaning it has a direct or indirect effect of mutual influence, which further influences the OGB intention. Therefore, based on the abovementioned, this study mainly used the $\mathrm{C} 2 \mathrm{C}$ model as the context of OGB and explored the factors influencing consumers' OGB intention.

As people are social animals living in many groups, OGB easily initiates the impulse to shop. In addition to observing the consumption behaviors of these groups, other people are influenced by these groups, which is shown in their consumer decisions and consumption behaviors. In other words, when people are in a group, they often make decisions based on the influence of the majority and will follow the thinking or behaviors of the majority without much consideration, which is what psychologists call "conformity behaviors" [4]. In social psychology, conformity behaviors refer to individuals' tendency to change their minds or behaviors in the face of peer pressure, allowing them to think or behave similarly to the group [5]. In other words, an individual perceives the pressure from significant others or groups (e.g., parents, spouse, friends, and colleagues) about whether they need to perform a specific behavior. The stronger the positive subjective norm is, the more likely it is to urge people to perform such behavior. The herd theory also advocates that the current behavior of people can be affected by observing previous behaviors of others, where in most cases people merely observe without considering and evaluating a certain behavior [6-8]. Especially when consumers are hesitant to purchase something, they often seek information about relevant commodities from groups who have bought such commodities to reduce the risk and uncertainty of buying a new product. For example, when consumers make purchase decisions, they tend to follow the trend. While the previous studies of OGB focused on bargaining [9-11], less attention was paid to the study of the impact of conformity on OGB behavior [12]. Therefore, this study discussed the factor of conformity influencing OGB intention.

Customer engagement refers to the recognition of the emotional connection or behavioral relationship between the customer and the brand or organization [13], which is built through long-term and mutual interaction, communication, and good customer experience, and the customer can resonate, then react and generate interaction. In this study, the groups for OGB were composed of relatives and friends who knew each other, and the socioemotional relationship between acquaintances and friends had been established on a certain basis; thus, when these groups participated in OGB, it was more likely to cause positive customer engagement. Gartner found that up to $74 \%$ of consumers rely on social networks (communities) to guide their purchasing behaviors. Although previous studies focused on discussing the variables of buying intentions, such as price [9-11], perceived risks [14,15], and conformity behaviors [12], few scholars took customer engagement as a variable of OGB. Therefore, this study emphasizes the mediating effect of customer engagement, taking it as one of the variables affecting OGB intention [13].

Finally, based on the TPB theory, in addition to attitudes and subjective norms, perceived behavioral control (PBC) is also a crucial factor in predicting consumer behavior intentions. When studying the factors affecting consumers' exchange intentions regarding digital coupons, it was proposed to add perceived behavioral control to the TPB model as a variable, demonstrating a better interpretation than the TRA model [16]. In an OGB environment, users may face potential risks, such as insufficient information about the product before purchase to make an assessment, concerns about potential risks, such as errors in product returns or replacement, as well as the privacy and security of information and price transparency [17]. These perceived risks could arise even for consumers shopping in a physical environment, which in turn can influence their decision-making in 
purchasing [18]. For consumers engaged in OGB, because they cannot confirm whether the product meets their expectations or find that it is not used after the purchase, they have the sense of losing money. Therefore, when consumers perceive greater risks of OGB products, they are uneasy or hesitant to make purchases, which may further decrease the consumer's OGB intention, and vice versa, increase the OGB intention. Therefore, this study used perceived risks as an interference factor that influences the relationship between customer engagement and OGB intention.

In conclusion, the contributions of this study are shown as follows:

(1) OGB is a new transaction model of e-commerce. The previous studies focused on the discussion of the B2C and C2B OGB model. However, less attention was paid to the C2C OGB model. The discussion of this study can be conducive to supplementing the lack of literature on the $\mathrm{C} 2 \mathrm{C}$ transaction model of OGB.

(2) The research results have substantial contributions to the prediction of online consumer behavior (especially of the participants of OGB) and the operation of OGB platforms. According to the results, it is recommended that OGB platforms improve customer engagement when they attract potential customers and convert them into buyers. They should also build good community relationships through social media [19-21] so that the word-of-mouth effect extended from conformity behaviors can be strengthened. Furthermore, they should adopt management mechanisms to ease the insecurity of consumers while participating in OGB. They may provide a complete return and exchange mechanism, return the price difference if the purchasing price is proven to be higher, or provide a warranty policy.

(3) The research results echo the studies conducted by many scholars, explaining the consumer's OGB attitudes and intentions based on the theory of consumer behaviors [1,17,22-30]. Moreover, by taking customer engagement as the mediating factor of consumers' conformity behaviors and OGB intention, this study explored the emotional connection established by conformity behavior on the OGB platform and the resultant sharing. As a result, the OGB intention was further improved.

The above results have substantial contributions to both the consumer behavior theory and the marketing theory [30]. Based on the perspective of consumer behaviors, this study firstly probed into the relevant factors that can affect consumers' OGB intention. Meanwhile, based on the angles of consumers' conformity behaviors and customer engagement, this study explored their influence on consumers' OGB intention. Lastly, the interference effect of consumers' perceived risks of OGB platforms for customer engagement and OGB intention were discussed.

\section{Literature Review and Hypotheses Development}

\section{1. $O G B$}

Since the financial tsunami in 2008, OGB has steadily gained its market share in the overall retail market. The annual turnover of the global OGB market is USD 5 billion. The market leader, Groupon, has more than 43 million customers globally, with a turnover of more than USD 2.2 billion [26,31]. OGB, which is a form of quantity discount that reduces the price due to the increased demand by aggregating consumer demands, is a new type of e-commerce model [2]. OGB is attractive in two ways; one is that the price of OGB is lower than the price of general physical or online shopping and the other is that consumers can freely choose to join OGB and receive the quantity discount, which gives consumers bargaining power against suppliers [18]. That is, as the bargaining power between consumers and sellers increases when the number of consumers increases, OGB enables sellers to reduce the cost of attracting new consumers and enables consumers to buy products at lower prices [1]. In OGB, consumers are able to purchase products at a discounted price and sellers are able to retain the existing consumers and attract new consumers, thus, this transaction model enables both parties to create value together.

As the online shopping market gradually matures, the convenience of online transaction methods becomes better than that of physical stores, and because network shopping 
eliminates the restrictions of time and space, three kinds of OGB business models have been developed. The first type is the business-to-customer (B2C) model. In this OGB model, businesses provide specific products on their platform (such as GOMAJI, Yahoo Super Mall, Rakuten Market, and Amazon), and consumers who are interested in these products must buy a certain number of the products within a certain period of time to receive a discount; thus, this model is intended to provide specific products, meaning that consumers may not be able to buy the required products.

The second type is the customer-to-business (C2B) model, which is also called the independent third party-initiated model. In this model, online platforms (such as ihergo and 17iLife e-commerce) provide a variety of products, and consumers can find the products they need. When this group of consumers is interested in a certain product, they actively gather a large number of consumers interested in this product and then bargain with the seller to receive better discounts.

The third type is the customer-to-customer (C2C) model, which is not initiated by businesses or an independent third party, but by the consumers themselves, who call on friends, family members, and office colleagues to gather and purchase the products together when they have the same purchase demand to achieve the purchasing goal of reducing the price (e.g., using Shopee, Yahoo Auction, Line communities, and Facebook communities). Therefore, this group of consumers does not deliberately gather due to being members of an established buying group but naturally gather due to the same living environment [18].

Previous studies of the issues related to OGB usually focused on the business-tocustomer and independent third-party platform-to-customer models to explore shopping intentions; for example, Ref. [1] explored the causes and consequences of OGB intention from the perspective of the theory of planned behavior (TPB); Ref. [32] used price, waiting time, and demand as the interference variables, and explored the willingness of OGB based on the theory of cognitive equity; Ref. [33] used social capital and platform synergies to influence the development of OGB consumers through the mediating effect of customer engagement; Ref. [26] determined consumers' intentions to engage in OGB according to the perceived values and perceived trust of consumers, as well as the influence of sensitivity on interpersonal relationships; Ref. [18] targeted OGB initiated by friends and family members who had participated in OGB and how they influenced OGB intention with valuable, emotional, and evaluative social recognition through perceived values, perceived risks, and cognitive efforts. As few scholars have studied the customer-to-customer (C2C) consumerinitiated OGB model, this study took the transaction model initiated by consumers as the main subject of OGB.

\subsection{Group Buying Intention}

"Intention" indicates the probability of an individual taking action, meaning when the individual realizes they have the ability, resources, and opportunities to perform a particular behavior, the individual feels they have increased control, and their intention to act also increases [1]. Making purchasing decisions is a complex process, and the buying intention is often related to views and attitudes about consumer behaviors; Ref. [34] pointed out that the buying intention is the probability that a consumer will attempt to purchase the product, and the higher the buying intention, the higher the probability of purchasing the product.

Previous studies considered consumers' online transaction behaviors or psychological tendencies as an intention. For instance, Refs. $[16,35,36]$ pointed out that consumers' use of the digital coupon redemption behavior can be regarded as the intention for digital coupon redemption. The above studies analyzed the key factors affecting consumers' digital coupon redemption intention based on the TRA, the TPB, and the unified theory of acceptance and use of technology (UTAUT). Such factors included attitudes, subjective norms, and perceived behavioral control. In [37], it was pointed out that consumers' attitudes toward advertising and adoption of location-based coupons could positively affect their intention to use such coupons. On the other hand, in the study on the prerequisites for affecting 
consumers' transactions on the existing bargain sites, Ref. [38] indicated that consumers characterized by price orientation, enjoyment, market mavenism, and shopping smart could positively affect consumers' intention to buy at the existing bargain sites. However, they also pointed out that consumers with value consciousness and high perceived risks have less intention to buy at such sites. Meanwhile, this study concluded that the concept of consumers' willingness to redeem digital coupons, using location-based coupons online, and buying at the existing bargain sites also applies to OGB platforms.

As this study explored OGB, the buying intention referred to the intention to participate in OGB, that is, the willingness of a consumer to engage in the consumption behavior of OGB; Ref. [39] defined OGB intention as the intention of an individual to engage in OGB $[26,40]$.

The previous studies pointed out that consumers with a higher degree of involvement in OGB platforms have a higher OGB intention [26]. In the past, many scholars generally analyzed the OGB behaviors of individuals or groups through the intention to participate in OGB platforms $[21,26,27,29,41-43]$. As the OGB intention of an individual can be regarded as the possible buying behavior of the consumer [44] or a kind of consumer decisionmaking, the OGB participation intention can also be treated as the consumer's buying behavior at OGB platforms [29]. According to the marketing literature on the factors affecting consumers' online buying intentions in the past, such factors are mainly derived from the consumers' perceived value of the product [45-47], perceived quality [48,49], perceived risks [50,51], and perceived purchase equity [15,52].

\subsection{Conformity Behavior and Online Group Buying Intention}

Conformity behavior is a type of convergent social behavior [4]. Ref. [53] was one of the first scholars to propose the concept of "conformity" and argued that the behavior of conformity means that individuals in a group, whether voluntarily or involuntarily, obey the opinions of the majority, accept the influence of the group, and change their behaviors or thoughts accordingly. In daily life, conformity behavior is a very common behavior; for example, when a person's friends want to buy an item, although not interested in this item, he/she will also buy it to avoid being labeled as especially unsociable, and this is an occurrence of conformity behavior; Ref. [54] argued that conformity behavior is informational influence and normative influence under social influences.

"Informational influence" means that individuals change their initial ideas and values and, further, their consumption behaviors through external sources, such as reviews, reputation, and blogs [55]. The most important concept of informational influence is "internalization", which means that when consumers have uncertainty or lack relevant knowledge, they seek external assistance (e.g., friends, relatives, reference groups) to change their views and values [56], and thus conformity behavior appears. "Normative influence" is also known as subjective norms or social influence, which are associated with social pressures to agree or disagree with the expected behaviors of others [55]. Normative influence includes obedience and identity, where obedience means to make others have a positive view of themselves to avoid punishment or receive a reward [56], while identity refers to the conformity behavior pattern that occurs when a group performs a certain behavior, and individuals do the same to maintain a good relationship with the group and conform to the expectations of the group.

It was pointed out previously that when doubts arise during the OGB process, the doubters often listen to the opinions of others as a reference, especially the sharing and communication among colleagues, thereby increasing the willingness to engage in OGB [57]. In addition, Ref. [58] pointed out that when consumers have insufficient information, they would likely make judgments by observing others or listening to the opinions of others, and when the number of group buyers is larger, the conformity behavior is higher and consumers are more likely to have the willingness to buy. Therefore, in OGB, consumers refer to or obey the opinions of others due to insufficient grasp of product information or because of pressure from relatives and friends when making purchasing decisions; thus, 
when consumers decide whether to participate in OGB, there may also be conformity behavior. To sum up, this study proposed $\mathrm{H} 1$ as follows:

Hypothesis 1 (H1). Conformity behavior has a positive impact on OGB intention.

\subsection{Conformity Behavior and Customer Engagement}

In addition to meeting the customer's own needs for the product price, appearance, and functionality, there are many factors that determine a consumer's purchase decision, including the influence exerted by the behavior of other group members; Ref. [8] studied how conformity behavior on social media (Facebook, IG) influences user intention and pointed out that while an individual may have had no intention of clicking on the advertising message or reading the sponsored advertising content, they would later see other people (such as good friends, close friends, group members) "like", appraise, or even leave a post and share the product, change their mind, and click on the advertising content and even visit the brand's website. The above displays the two major characteristics of conformity buying: one is when consumers may not really like or need the product, they know little about the product, and their motivation to buy is caused by the influence of the group; the second is that an individual has a demand for a certain product, but their choice of brand is not based on analysis or any assessment criteria, but by the products commonly used by the group members. Therefore, in OGB involving friends and relatives, individuals invest energy, effort, and time in interactions in the community and participate in OGB to maintain emotional engagement among friends and relatives or meet their expectations. To sum up, this study proposed $\mathrm{H} 2 \mathrm{a}$ and $\mathrm{H} 2 \mathrm{~b}$ as follows:

Hypothesis 2a (H2a). Conformity behavior (normative influence) has a positive impact on customer engagement.

Hypothesis $\mathbf{2 b} \mathbf{b} \mathbf{H} \mathbf{2 b})$. Conformity behavior (informational influence) has a positive impact on customer engagement.

\subsection{Customer Engagement and OGB Intention}

While the concept of customer engagement has been discussed for more than ten years, the previous discussions focused on the behavioral level [59], where customer engagement was defined as customers' engagement in the subject (company/brand/community), including the brand reputation, recommendations and content generation, and suggestions [60]. Some scholars have also pointed out that, in addition to behavioral engagement, customer engagement includes customers' continuous links between psychology and the subject (company/brand/community) [13,61]; Ref. [62] defined customer engagement as customers' attitudes at the psychological level or engagement at the behavioral level through repeated interactions, thereby enhancing a strong connection to the organization or brand; Ref. [63] suggested that customer engagement referred to the customer's direct or indirect contribution to the organization, thereby increasing the value of the organization, where direct contribution referred to customers making purchases, while indirect contribution referred to customers' non-transactional behaviors towards the company, including all positive recommendations, feedback, and suggestions posted on social media. In this study, the groups for OGB were composed of relatives and friends who knew each other, and the socioemotional relationship between acquaintances and friends was established on a certain basis; thus, when these groups participated in OGB, it was more likely to cause positive customer engagement.

In previous studies of customer engagement, most scholars divided customer engagement into two elements: the psychological level and the behavior level. Studies on the psychological level mainly discussed the degree of customer engagement in the activities initiated by organizations or the strength of the relationship between the businesses and the customers [62], where psychological engagement included trust, satisfaction, commitment, customer value, and loyalty to and emotional connection with the organization [64]. Thus, 
the higher the connection between the customer and the organization, the higher the level of cognition and emotional factors, which also means higher customer engagement.

Ref. [65] found that customer engagement positively influences buying intentions as customers indirectly increase their willingness to buy through repeated interactions and engagement in the organizations' activities; Ref. [66] stated that customer engagement through mobile applications indirectly imposes positive influences on buying intentions; Ref. [67] also found that increased customer engagement significantly influences the willingness to buy, which in turn attracts customers' attention to the brand and further increases their willingness to buy. In this study, acquaintances and friends actively participated in the discussions, sharing, and suggestions about OGB and were psychologically loyal to the group, meaning the concept of customer engagement was established, which may have also positively influenced their intentions to engage in OGB. To sum up, this study proposed H3 as follows:

\section{Hypothesis 3 (H3). Customer engagement has a positive impact on OGB intention.}

\subsection{The Moderating Role of Perceived Risks}

Perceived risk was first incorporated into the field of marketing management by [68] who indicated that consumers would have some unpredictable sense of uncertainty about the outcome of the actions taken, which would make them feel unpleasant; thus, consumer behaviors could be regarded as an instance of risk taking. However, Ref. [69] further proposed that when consumers make a purchase and perceive that their purchasing behavior does not reach the expected target, they would perceive risks, which would also influence the consumption behaviors. If the perceived risks cannot be accepted, the consumer would take actions to reduce risks to increase their purchase confidence; Ref. [70] pointed out that when faced with perceived risks, users could reduce the degree of perceived risks to an acceptable range by reducing the uncertainty of their perception or reducing possible losses.

Currently, due to the maturing development of the Internet, there are changes to consumption patterns, and online stores are full of goods that provide more product information than traditional channels. However, since Taiwanese consumers are still accustomed to actually seeing and touching the product before purchasing it, consumers have increased perceived risks of shopping on the Internet compared to traditional channels [71]; Ref. [72] found that consumers of live shopping platforms would have more fear of unfamiliarity with products or stores if they had no relevant experience; thus, their perceived risks would increase; Ref. [73] mentioned that consumers face risks in the B2C business environment, such as goods traded online having worse product benefits than expected, loss of personal privacy during online shopping, and wasting too much time, money, or effort; Ref. [74] pointed out that in the $\mathrm{C} 2 \mathrm{C}$ environment, users face higher risks than on $\mathrm{B} 2 \mathrm{C}$ e-commerce platforms because such transaction models are not actually in contact with buyers, and consumers also have concerns about the personal characteristics of the sellers and buyers, which thereby increases the perceived risks.

Individuals live in groups. In addition to family groups, the groups we frequently interact with may include friends and colleagues; Ref. [75] pointed out that when consumers' perceived risks become higher during purchasing decisions, the information provided through reference groups appears more important than information from other sources; thus, consumers listen to their suggestions, thereby reducing their OGB intention. In contrast, the OGB intention is increased. To sum up, this study proposed $\mathrm{H} 4$ as follows:

Hypothesis 4 (H4). When consumers have high perceived risks, the positive effect of customer engagement on OGB intention is reduced.

\subsection{The Mediating Role of Customer Engagement}

Conformity is seen as part of leading group behaviors regardless of gender, age group, and even different levels of education [76]; for example, users of social media increase their engagement to obtain a sense of identity and self-identity with the influencers they follow, 
such as users wanting to buy the same product as the influencer, which increases their attention to the product and even their willingness to buy [67]; Ref. [65] found that the customer's business identity requires increased customer engagement to have a significant impact on their willingness to buy again, meaning that companies must establish customer loyalty to encourage customers to buy again. According to the above, it can be concluded that between the prerequisites and the buying intention, customer engagement can be used as a variable with a mediating effect, as well as the effect of increasing the buying intention. To sum up, this study proposed $\mathrm{H} 5$ as follows:

Hypothesis 5 (H5). Customer engagement has a mediating effect between conformity behavior and $O G B$ intention.

\section{Research Method}

\subsection{Research Framework}

This study mainly explored the influence of consumers' conformity behaviors and customer engagement on OGB intention and took the perceived risks on OGB platforms as an interference factor. The concept of conformity behaviors was mainly derived from the herd theory proposed in [6]. According to the theory, the individuals' behaviors can be affected by observing previous behaviors of others, similarly to the behaviors of a flock of sheep [6,8]. OGB is more likely to result in impulsive shopping behavior because in addition to their own attitudes, individuals' behaviors can also be affected by social influence-for instance, the opinions of leaders or the majority [12,77] or the influence of members in other groups [12,78]. These influences will further affect their decision-making and consumption behaviors, especially on online transaction platforms, as the information is often asymmetrical. Therefore, when consumers buy products on such platforms, they worry about the risks of buying poor-quality products. From the argument of the herd theory, conformity behaviors are an important prerequisite for predicting consumers' OGB intention $[12,79]$.

In the business environment of OGB platforms, eWOM is a phenomenon of information exchange among consumers [80]. Such a phenomenon reflects the conformity mentality of consumers. Therefore, before buying, consumers would get information about products through the recommendations of the OGB platforms to decrease the risks of information insufficiency. Moreover, in terms of the normative influence of social interactions, like-minded consumers would interact with each other [81]. Such interaction is similar to conformity behaviors of consumers. In other words, consumers tend to buy products recommended by OGB platforms to obtain a sense of identity and belonging, as well as meet the expectations of such platforms. Therefore, this study proposed that conformity behaviors could affect customer engagement $[82,83]$. In addition, previous studies pointed out that customer engagement could positively affect buying intentions $[66,84]$. For instance, consumers actively share on social media platforms and give positive comments on shared content by giving "likes" [85]. In this way, consumers will start paying attention to the brand and enhance their buying intentions. Therefore, this study regarded customer engagement as positive engagement for individuals to participate in OGB events consisting of friends and relatives. From the psychological facet of such participation, as individuals and their friends and relatives have established a certain emotional connection, they become more loyal to such OGB. From the participation behaviors, buying intentions toward OGB platforms can be enhanced as friends and relatives discuss the products they bought on these platforms. In conclusion, customer engagement may have a mediating effect on consumers' conformity behaviors and OGB intention.

Lastly, customers may have perceived risks when shopping if they perceive that particular buying behaviors could not meet their expectations. The mentality of such perceived risks is more distinct in online transactions. Consumers may take evasive measures if they perceive the potential risks of a transaction to reduce their losses [86,87]. As a result, consumers are less likely to participate in OGB platforms if they doubt the transactions involved. In conclusion, this study proposed that perceived risks might 
regulate the relationship between customer engagement and OGB intention. The construct of this study, based on the above premises, is shown in Figure 1:

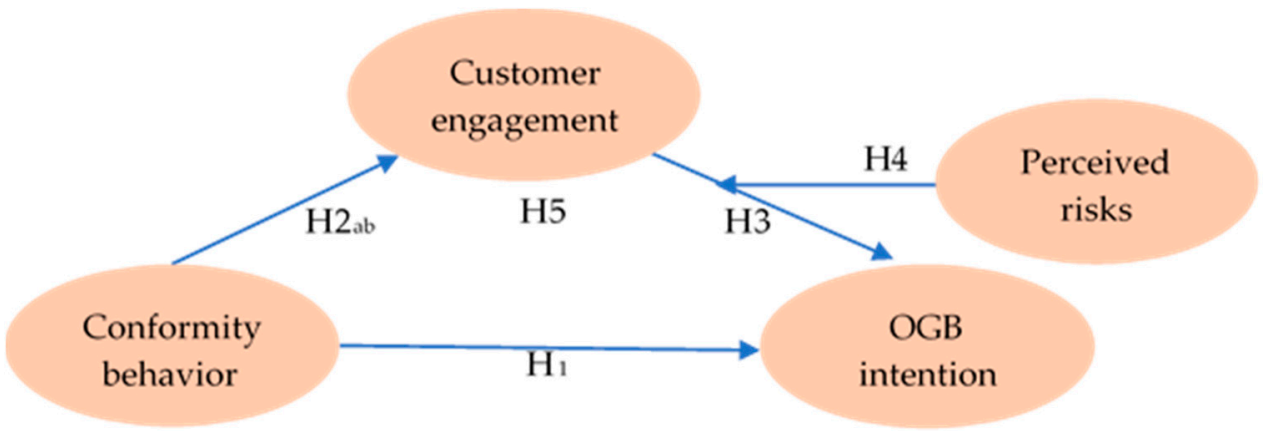

Figure 1. Conceptual model.

\subsection{Research Subjects}

The subjects of this study were consumers who participated in buying from OGB platforms initiated by their friends and relatives. The questionnaires were distributed to those consumers with experience in OGB online. The consumers, selected by snowball sampling, were invited to pass the questionnaires to other consumers with OGB experience. The period from distributing to receiving the questionnaires was seven weeks, starting from 12 January to 21 March 2021.

\subsection{Measurement Development}

This study included four constructs, including conformity behaviors, customer engagement, perceived risks, and OGB intention. We used the established scale in the available literature to measure the variables. Then, we modified the variable design according to the situation. In addition, the measurements of the research constructs in this paper were scored on a five-point Likert scale ranging from 1 (strongly disagree) to 5 (strongly agree) applied for all the selected measures. To improve translation equivalence, translation and back translation procedures were performed by different bilingual Chinese-English assistants. Conformity behaviors items were adapted from [55]; customer engagement items were adapted from [13]; perceived risks items were adapted from [88] and [15]; OGB intention items were adapted from [15].

\section{Research Results}

\subsection{Data Collection and Demographic Characteristics of the Participants}

In this study, 322 samples were collected in total; 26 invalid questionnaires were excluded due to incomplete answers or respondents having no OGB experience on OGB platforms in the previous six months, leaving a total of 296 valid questionnaires.

As indicated in Table 1, preliminary analysis of the questionnaires found that women comprised the majority with OGB experience on community e-commerce platforms (62.8\%); the largest age group was under 25 years old (25.3\%), followed by people $41-45$ years old $(18.6 \%)$, 46-50 years old $(18.2 \%)$, and older $(18.2 \%)$. In terms of educational status, most were university and college graduates (62.5\%), followed by high school graduates (vocational high school graduates) $(22.0 \%)$. In the previous six months, the number of experiences of OGB on community e-commerce platforms was mostly less than 5 (69.9\%), followed by 6-10 times (17.9\%). The majority of the participants $(52.0 \%)$ were from the northern region.

\subsection{Verification of Non-Response Bias}

To ensure the collected data posed no concern of non-response bias, we evaluated non-response bias by comparing early and late respondents on demographic variables and model constructs [89]. The result showed no significant differences between the early and late respondents, suggesting that non-response bias was not a concern. 
Table 1. Demographic characteristics of the participants.

\begin{tabular}{|c|c|c|c|}
\hline Profile & Category & Number & Percentage $(\%)$ \\
\hline \multirow{2}{*}{ Gender } & Male & 110 & $37.2 \%$ \\
\hline & Female & 186 & $62.8 \%$ \\
\hline \multirow{7}{*}{ Age } & $\leq 25$ & 75 & $25.3 \%$ \\
\hline & $26-30$ & 18 & $6.1 \%$ \\
\hline & $31-35$ & 11 & $3.7 \%$ \\
\hline & $36-40$ & 29 & $9.8 \%$ \\
\hline & $41-45$ & 55 & $18.6 \%$ \\
\hline & $46-50$ & 54 & $18.2 \%$ \\
\hline & $\geq 51$ & 54 & $18.2 \%$ \\
\hline \multirow{4}{*}{ Education } & Junior high school or below & 4 & $1.3 \%$ \\
\hline & Senior high/technical & 65 & $22.0 \%$ \\
\hline & University or college & 185 & $62.5 \%$ \\
\hline & Master's or above & 42 & $14.2 \%$ \\
\hline \multirow{4}{*}{ Living area } & North & 154 & $52.0 \%$ \\
\hline & Central & 91 & $30.7 \%$ \\
\hline & South & 49 & $16.6 \%$ \\
\hline & East & 2 & $0.7 \%$ \\
\hline \multirow{5}{*}{ OGB experience (times) } & $\leq 5$ & 207 & $69.9 \%$ \\
\hline & $6-10$ & 53 & $17.9 \%$ \\
\hline & $11-15$ & 19 & $6.4 \%$ \\
\hline & $16-20$ & 11 & $3.7 \%$ \\
\hline & $\geq 21$ & 6 & $2.0 \%$ \\
\hline
\end{tabular}

\subsection{Common Method Variance (CMV)}

In this study, we adopted the procedural remedies of protecting respondent anonymity, reducing item ambiguity, and listing items for dependent variables prior to those for independent variables [90]. We also used Harman's one-factor test to check for this potential problem [91]. The result showed that eight factors account for $75.07 \%$ of the variance and the first factor accounts for $26.09 \%$ of the variance. Hence, common method variance was not a concern.

\subsection{Reliability and Validity Analysis}

Cronbach's alphas of all the constructs ranged from 0.912 and 0.779 , showing good reliability. Confirmatory factor analysis (CFA) using Lisrel 8.7 was conducted to examine the validity. This study avoided the violation of the five-to-one ratio of sample size to parameter estimate by establishing two CFA models [92]. Model I contained two constructs, conformity Behavior and customer engagement, and Model II consisted of the other two constructs, perceived risks and OGB intention. The CFA result indicated a good model fit for both models (see Table 2). All the items in both models loaded significantly on their respective first-order constructs (standard factor loadings ranged from 0.64 to 0.90 ). The composite reliabilities (CR) in all the cases exceeded 0.7 ; all the average variance extracted (AVE) values were near or higher than the recommended level of $0.5[93,94]$. Thus, the convergent validity of constructs was acceptable. An analysis of the validity factors is presented in Table 2. 
Table 2. Items, reliability, and results of the CFA.

\section{Item}

Model I $\mathrm{X}^{2}=228.27, p<0.001, \mathrm{RMSEA}=0.067, \mathrm{CFI}=0.95, \mathrm{NFI}=0.91, \mathrm{GFI}=0.91$

Conformity behavior-normative influence $(\mathrm{AVE}=0.53, \mathrm{CR}=0.87)$

I realy purchase the latest fashion styles until I am sure my friends approve of them

0.64

It is important that others like the products and brands I buy

0.73

When buying prodcts, I generally purchase those brands that I think others will approve of.

0.74

If others people can see me using a product, I often purchae the brand they expect me to buy

0.83

I like th know what brands and producs make good impressions on others

0.71

I achieve a sens of belonging by purchasing the same products and brands that others purchase.

0.72

Conformity behavior-informational influence $(\mathrm{AVE}=0.54, \mathrm{CR}=0.78)$

To make sure I buy the right product or brand, I often observe what others are buying and using

0.73

If I have little expericnce with a product, I often ask my friends about the product

0.77

I frequently gather information form friends or family about a product before I buy

Customer engagement-psychological level $(\mathrm{AVE}=0.66, \mathrm{CR}=0.88)$

I am heavily into this community

I pay a lot of attention to anything about this community

0.78

Anything related to this community grabs my attention

0.88

I enjoy $t$ this community more when I am with others

Customer engagement-behavioral level $(\mathrm{AVE}=0.65, \mathrm{CR}=0.84)$

I do things to make the community's job easier

0.86

I provide the community some useful suggestions to improve services

0.85

I help other members get what they need within this community

Model II $X^{2}=112.19, p<0.001$, RMSEA $=0.055, \mathrm{CFI}=0.98, \mathrm{NFI}=0.96, \mathrm{GFI}=0.94$

Perceived risks-financial risk $(\mathrm{AVE}=0.79, \mathrm{CR}=0.92)$

I would be concerned that I really would be a bad way to spend my money 0.87

I would be concerned that the financial investment I would make woud not be wise.

I would be concerned that I really would not get my money's worth form the product

Perceived risks-performance risk $(\mathrm{AVE}=0.68, \mathrm{CR}=0.86)$

I worry about whether the product will really perform as well as it is supposed to 0.84

I become concerned that the product will not provide the level of benefits that I would be expecting

Cases me to be concerned for how really dependable and reliable that product will be

Perceived risks-psychological risk $(\mathrm{AVE}=0.79, \mathrm{CR}=0.91)$

Buying a product on OGB sites makes me feel psychologically uncomfortable

Buying a product on OGB sites gives me a feeling of unwanted anxiety

Buying a product on OGB sites causes me to experience unnecessary tension

0.89

OGB intention $(\mathrm{AVE}=0.71, \mathrm{CR}=0.90)$

I intend to make OGB sites my primary platform for online purchases 0.80

I intend to regularly use OGB sites 0.81

I intend to make future purchases from OGB sites 0.88

I intend to continue using OGB sites 
Following [54], this study treated conformity behavior as a second-order construct with two dimensions. Customer engagement was also considered a second-order construct $[62,64]$. Subsequently, two second-order CFAs for conformity behavior and customer engagement were run separately. Table 3 shows that both second-order constructs had a good model fit. Hence, we employed the higher-order constructs of conformity behavior and customer engagement in the hypothesis testing.

Table 3. Second-order CFA for conformity behavior and customer engagement.

\begin{tabular}{ccc}
\hline Second-Order Construct & First-Order Dimension & Loadings \\
\hline Conformity behavior $\left(\mathrm{X}^{2}=65.07, \mathrm{RMSEA}=0.071\right.$, & Normative influence & 0.83 \\
\cline { 2 - 3 } $\mathrm{NFI}=0.94, \mathrm{CFI}=0.96, \mathrm{NNFI}=0.95, \mathrm{GFI}=0.95)$ & Informational influence & 0.78 \\
\hline Customer engagement $\left(\mathrm{X}^{2}=51.75, \mathrm{RMSEA}=0.075\right.$, & Psychological level & 0.97 \\
\cline { 2 - 3 } $\mathrm{NFI}=0.96, \mathrm{CFI}=0.97, \mathrm{NNFI}=0.95, \mathrm{GFI}=0.95)$ & Behavioral level & 0.75 \\
\hline
\end{tabular}

In terms of differential validity, in line with the method proposed in [93], this paper required that the open squared value of the average variation extraction (AVE) of each potential variable be greater than the absolute value of the correlation coefficient between the paired variables. Table 3 shows that there was a positive relationship between the facets and the coefficients did not exceed 0.8 [95], and the open squared values of AVE of all the potential variables were between 0.714 and 0.877 , which is greater than the correlation coefficient of $-0.241 \sim 0.663$. In other words, the significance of the difference between the concepts in this study was obvious, which means that the structure of this study was reasonable and there was no serious collinearity problem; thus, the correlation between the concepts in this study could be further explored through regression analysis. Analysis of the means, standard deviations, and correlation coefficients is provided in Table 4.

Table 4. Results of discriminant validity tests.

\begin{tabular}{|c|c|c|c|c|c|c|}
\hline & 1 & 2 & 3 & 4 & 5 & 6 \\
\hline $\begin{array}{l}\text { 1. Conformity } \\
\text { behavior-normative influence }\end{array}$ & 0.728 & & & & & \\
\hline $\begin{array}{l}\text { 2. Conformity } \\
\text { behavior-informational influence }\end{array}$ & $0.518^{* *}$ & 0.734 & & & & \\
\hline $\begin{array}{l}\text { 3. Customer } \\
\text { engagement-psychological }\end{array}$ & $0.271^{* *}$ & $0.284^{* *}$ & 0.812 & & & \\
\hline $\begin{array}{l}\text { 4. Customer } \\
\text { engagement-behavioral }\end{array}$ & $0.307^{* *}$ & $0.287^{* *}$ & $0.663^{* *}$ & 0.806 & & \\
\hline 5. Perceived risks & 0.024 & -0.081 & $-0.302 * *$ & $-0.241^{* *}$ & 0.877 & \\
\hline 6. OGB intention & $0.194^{* *}$ & $0.192 * *$ & $0.536^{* *}$ & $0.473^{* *}$ & $-0.272^{* *}$ & 0.842 \\
\hline Mean & 2.41 & 2.73 & 2.29 & 3.61 & 3.64 & 3.42 \\
\hline Standard deviation & 0.62 & 0.61 & 0.65 & 0.56 & 0.57 & 0.61 \\
\hline
\end{tabular}

Note: Diagonals represent the square root of the average variance extracted. Other entries represent the intercorrelations of the constructs. ${ }^{* *} p<0.01$.

\subsection{Regression Analysis}

The hypotheses were tested using SPSS 25.0. To reduce the possibility of multicollinearity, both the independent and the moderating variables were mean-centered before producing the term [96]. Moderated hierarchical regression analyses were then used to test the hypotheses $[97,98]$. It can be seen from the F-value in Table 5 that the total verification effect reached a significant level $(p<0.001)$, which indicates that the regression pattern reached a significant level, and the adjusted explanatory variation was ca. $34 \%$. 
Table 5. Result of the regression analysis.

\begin{tabular}{|c|c|c|c|c|c|c|}
\hline & \multicolumn{4}{|c|}{ OGB Intention } & \multirow{2}{*}{$\begin{array}{c}\begin{array}{c}\text { Customer } \\
\text { Engagement }\end{array} \\
\text { Model } 5 \\
\end{array}$} & \multirow{2}{*}{$\begin{array}{c}\text { OGB Intention } \\
\text { Model } 6 \\
\end{array}$} \\
\hline & Model 1 & Model 2 & Model 3 & Model 4 & & \\
\hline \multicolumn{7}{|l|}{ Control variable } \\
\hline OGB frequency & $0.150 * *$ & $0.081^{+}$ & 0.073 & 0.077 & 0.125 & $0.083^{+}$ \\
\hline Education & 0.062 & 0.059 & 0.048 & 0.038 & 0.009 & 0.057 \\
\hline \multicolumn{7}{|l|}{ Independent variable } \\
\hline $\begin{array}{l}\text { Conformity } \\
\text { behavior-normative } \\
\text { influence }\end{array}$ & $0.138 *$ & & & & $0.212^{* *}$ & 0.024 \\
\hline $\begin{array}{l}\text { Conformity } \\
\text { behavior-informational } \\
\text { influence }\end{array}$ & $0.116^{+}$ & & & & $0.206^{* *}$ & 0.006 \\
\hline Customer engagement & & $0.546^{* * *}$ & $0.515^{* * *}$ & $0.526^{* * *}$ & & $0.536^{* * *}$ \\
\hline \multicolumn{7}{|l|}{ Interference variable } \\
\hline Perceived risks (RC) & & & $-0.105^{*}$ & $-0.113^{* *}$ & & \\
\hline \multicolumn{7}{|l|}{ Interactive } \\
\hline $\begin{array}{l}\text { Customer engagement * } \\
\text { Perceived risks }\end{array}$ & & & & $-0.124^{* *}$ & & \\
\hline F-value & $5.71^{* * *}$ & $45.52^{* * *}$ & $35.60 * * *$ & $30.35^{* * *}$ & $12.31^{* * *}$ & $27.21^{* * *}$ \\
\hline $\operatorname{Adj} R^{2}$ & 0.061 & 0.319 & 0.329 & 0.344 & 0.133 & 0.308 \\
\hline VIF & 1.416 & 1.014 & 1.117 & 1.122 & 1.416 & 1.466 \\
\hline
\end{tabular}

According to Table 5 , for Model 1, conformity behavior (normative and informational) has a positive effect on buying intention $(\beta=0.150, p<0.05 ; \beta=0.116, p<0.1$, respectively); thus, H1a,b are supported. According to Table 5, for Model 5, conformity behavior (normative and informational) has a positive impact on customer engagement $(\beta=0.212$, $p<0.01 ; \beta=0.206, p<0.01$, respectively); thus, $\mathrm{H} 2 \mathrm{a}$, b are supported. According to Table 5 , for Model 2, the results show that customer engagement has a positive impact on buying intention ( $\beta=0.546, p<0.001)$; thus, H3 is supported.

Next, this study verified the interference effect of the perceived risks on customer engagement and OGB intention. According to Table 5, for Model 4, the interaction of perceived risks and customer engagement has a significant negative effect on OGB intention ( $\beta=-0.124, p<0.05)$, which indicates that the effect of perceived risks may be influenced in the process of customer engagement; thus, $\mathrm{H} 4$ is supported.

Finally, in conformity to the steps defined in [99], this study verified the mediating effect of customer engagement. According to Table 5, for Model 1, the conformity behavior (normative and informational) has a positive impact on OGB intention. Model 5 shows that conformity behavior (normative and informational) has a positive impact on customer engagement. Model 2 shows the influence of conformity behavior (normative and informational) and customer engagement on OGB intention, and the regression model reached a significant level $\left(\mathrm{F}=27.211^{* * *}\right)$, and after adding customer engagement, the effect of conformity behavior (normative and informational) on OGB intention was not significant. Therefore, the results show that customer engagement has a complete mediating effect between conformity behavior (normative and informational) and OGB intention; thus, H5 is supported. 


\section{Conclusions and Suggestions}

\subsection{Conclusions}

This study mainly explored the influence of consumers' conformity behaviors and customer engagement on OGB intention and took the perceived risks on OGB platforms as an interference factor. The results of this study show that $\mathrm{H} 1$ is supported, which indicates that conformity behavior has a positive effect on OGB intentions. When they lack product information, consumers can receive beneficial information by referring to the opinions of other groups, or they will participate in OGB because of the pressure from their friends and family members and the desire to receive the recognition of the group. Therefore, the occurrence of conformity behaviors increases OGB intention, which echoes $[8,57,58]$ and other studies, that is, the number of "likes" and sharing in social media us influenced by conformity behavior; when individuals abandon their own ideas and follow the opinions of others due to the normative influence of peers and when individuals are uncertain or eager for correctness, they make choices by observing others or listening to their opinions, thereby improving the OGB intention. Therefore, in this study, when OGB was carried out between relatives and friends, conformity behavior at both the normative and informational levels positively influenced the OGB intention.

The results of this study show that $\mathrm{H} 2$ is supported, which indicates that conformity behavior has a positive impact on customer engagement. When friends and family members invite consumers to participate in OGB, consumers play an active role to maintain their feelings for each other or meet their expectations. When consumers encounter problems in OGB, meaning they lack relevant knowledge, they discuss the issue with friends and relatives or ask them to make recommendations, assessments, and suggestions in order to enhance consumer engagement in the OGB activities performed by friends and family members. Therefore, in this study, for consumers in OGB by relatives and friends, the normative influence or informational influence of conformity behavior increased engagement in OGB on such community e-commerce platforms.

The results of this study show that $\mathrm{H} 3$ is supported, which indicates that customer engagement has a positive impact on OGB intention. As there are considerable basic socioemotional relationships between acquaintances and friends when participating in OGB, it is more likely to cause positive customer engagement, and the OGB intention will be stronger. This conclusion echoes the findings of $[65,66]$ : i.e., customers who repeatedly interact and engage in organizing activities indirectly increase their willingness to buy; increased customer engagement increases the attention paid to the brand, which further increases the willingness to buy. Therefore, the active engagement of acquaintances and friends in OGB discussions, sharing, and other behaviors, and loyalty to the OGB community all directly influence the OGB intention.

The results of this study show that $\mathrm{H} 4$ is supported, which indicates that perceived risks have an interference effect between customer engagement and OGB intention, meaning each consumer has a certain tolerance for risks [76], and once the perceived risks become higher and even exceed their risk tolerance limit, the consumer may choose to abandon the purchase $[76,100]$. When the information from reference groups appears more important than information from other sources, the consumers listen to their advice, thereby reducing their OGB intention.

The results of this study show that $\mathrm{H} 5$ is supported, which indicates that customer engagement has a mediating effect between the conformity behavior and OGB intention and echoes the findings of [67]. Although the scope of the discussion topic was not exactly the same, there was a significant positive impact on buying intentions. This study found that when the discussion topic was included in the scope of OGB intention, customer engagement also had a mediating effect. This finding echoes that of some relevant studies $[13,101,102]$ that customer engagement has a mediating effect on behaviors and intentions. That is, customer engagement is a critical social interaction in the process of OGB transactions. Meanwhile, the research results also have substantial contributions to the literature of consumers' behaviors and marketing - the major finding of this study. 


\subsection{Research Implications}

In the previous studies of OGB intention, various prerequisites had a direct impact on buying intentions, such as perceived risks and conformity behavior [8,103], or indirect impact through other factors $[14,15,58]$ or perceived risks, such as the interference factor of conformity behavior and mediating variables that influence buying intentions [57,104]. This study explored the influence of conformity behavior on OGB intention and regarded perceived risks as interference factors. It is worth noting that participants in OGB often interact and share products or services on social media platforms $[13,100,105]$. This study further indicated that the phenomenon of network socialization is also key to affecting behaviors and intentions. Therefore, in order to completely understand the process of OGB of consumers, customer engagement was added as the mediating variable of the relationship discussed above. This endeavor is the first attempt in the discussion of OGBone of the main contributions of this study.

While [67] took customer engagement as the mediating variable to explore buying intentions for products advertised on social media and the electronic word-of-mouth intention [101], the difference from this study lay in the different prerequisites with the same effect on OGB intention. Therefore, this study suggested that in terms of theoretical implications, customer engagement can be regarded as an OGB intention and an important prerequisite of buying intentions and variable settings, such as the perceived risks and conformity behavior in the model, should be different from the previous studies and verified; thus, customer engagement as a mediating variable can be a new research area in subsequent studies on the related topics.

\subsection{Managerial Implications}

The results of this study show that perceived risks are a negative factor that influences OGB intention and customer engagement, which indicates that the perceived risks of consumers during OGB can easily cause the group's buying intentions to decrease and excludes customer engagement. However, many studies have shown that any consumption behavior may have unanticipated consequences for consumers, meaning that consumers have certain risks when making purchases $[15,68,88]$; thus, perceived risks are difficult for consumers to eliminate. However, this study found that customer engagement had a complete mediating effect between perceived risks and OGB intention, meaning that even if consumers perceive a risk, the level of customer engagement still influences the OGB intention; Ref. [63] found that consumer engagement positively influences the value of consumers to organizations; Ref. [62] pointed out that customer engagement referred to a strong connection and interaction between consumers' psychology, actions, and organizations; thus, in general, group buyers must reduce their perceived risks to improve OGB intention; for example, companies can establish a good warranty service or detailed return and exchange procedures for high-risk products, intangible products, or luxury goods, enhance consumer engagement with the company through trust and loyalty, and refer more to consumers' opinions of a product.

This study also found that the informational influence of conformity behavior was greater than the normative influence on customer engagement, which indicates that consumers are susceptible to informational influence and increased customer engagement; thus, when consumers have insufficient information or lack relevant knowledge of OGB, the comments or recommendations of their relatives and friends are influential. Therefore, in the application of group buyers, the possibility of products being purchased is increased when they are praised by many parties, and operators can improve their products by responding to bad reviews.

Overall, this study suggests that group buyers can focus more on consumer engagement, such as via OGB platforms that are designed to be easy to use, communicate quickly, and share information to enhance customer engagement; run social media associations to increase customer engagement; use more influential celebrity endorsements to make good use of the effectiveness of conformity behavior to increase customer engagement. 


\subsection{Research Limitations and Suggestions for Future Studies}

This study constructed the model structure and assumptions according to the practical phenomenon of community OGB and rigorous literature discussion; however, there are still deficiencies and limitations, as well as many topics that are worth exploring in the future, which are listed below.

Firstly, in terms of the product characteristic classification, the investigation of OGB products in this study did not specify or distinguish the products based on categories; at present, the main OGB products are food, clothing, and accessories, daily necessities, small household appliances / $3 \mathrm{C}$ products, and skincare products; however, the development of information technology and OGB continues to flourish and, coupled with the COVID-19 pandemic, OGB and community shopping products are becoming more and more diversified; for example, fresh vegetables and fruits, and cosmeceuticals ordered from overseas have become popular purchases. Therefore, future studies can use the classification of consumer goods to probe into whether the influence of community OGB on convenience goods, shopping items, and special items is different.

Secondly, while this study proposed that customer engagement plays a crucial role in both academic studies and practical implications, there are still many potential variables that can influence customer engagement. Therefore, it is recommended that subsequent studies use different research variables to influence customer engagement, such as perceived values, trust in initiators, and online reputation, to confirm the importance of customer engagement.

Furthermore, the $\mathrm{C} 2 \mathrm{C}$ mode was taken as the context of OGB in this study, and consumers with buying experiences on OGB platforms initiated by friends and relatives were selected as the subjects. Under such circumstances, the factors that can affect consumers' OGB intention were explored. As friends and relatives initiated OGB, a certain emotional connection and mutual trust was established between them. Therefore, they actively discussed and shared about OGB, which formed a small network relationship, but with the same nature. It is unclear whether the formation of this type of relationship can be applied to other networks. Thus, it is recommended to conduct further research in different contexts (such as live streaming).

Finally, among the respondents, female consumers comprised the majority (63.6\%); thus, the ability of this study to generalize the results for males is relatively lacking. In addition, the sample subjects were mostly from the north of Taiwan, and the largest age group of the respondents was under 25 years old; thus, future studies can collect samples based on gender, region, and age groups to ensure more representative research results.

Author Contributions: Conceptualization, C.-C.O. and Y.-Y.L.; methodology, W.-K.T.; software, K.L.C.; validation, C.-C.O., W.-K.T. and K.-L.C.; formal analysis, K.-L.C.; investigation, Y.-Y.L.; resources, W.-K.T.; data curation, W.-K.T.; writing-original draft preparation, C.-C.O.; writing-review and editing, W.-K.T.; supervision, C.-C.O.; project administration, W.-K.T. All authors have read and agreed to the published version of the manuscript.

Funding: This research received no external funding.

Institutional Review Board Statement: Not applicable.

Informed Consent Statement: Not applicable.

Data Availability Statement: Not applicable.

Conflicts of Interest: The authors declare no conflict of interest.

\section{References}

1. Cheng, H.H.; Huang, S.W. Exploring Antecedents and Consequence of Online Group-Buying Intention: An Extended Perspective on Theory of Planned Behavior. Int. J. Inform. Manag. 2013, 33, 185-198. [CrossRef]

2. Wang, E.S.T.; Chou, N.P.Y. Consumer Characteristics, Social Influence, and System Factors on Online Group-Buying Repurchasing Intention. J. Electron. Commer. Res. 2014, 15, 119-132.

3. Luo, X.; Andrews, M.; Song, Y.; Aspara, J. Group-Buying Deal Popularity. J. Mark. 2014, 78, 20-33. [CrossRef] 
4. Wang, G.P.; Chen, S.Y.; Yang, X.; Liu, J. Modeling and Analyzing of Conformity Behavior: A Fuzzy Logic Approach. Optik 2014, 125, 5694-6598. [CrossRef]

5. Kiesler, C.A.; Kiesler, S.B. Conformity; Addison-Wesley: Reading, MA, USA, 1969.

6. Banerjee, A.V. A Simple Model of Herd Behavior. Q. J. Econ. 1992, 107, 797-817. [CrossRef]

7. Bikhchandani, S.; Hirshleifer, D.; Welch, I. A Theory of Fads, Fashion, Custom, and Cultural Change as Informational Cascades. J. Polit. Econ. 1992, 100, 992-1026. [CrossRef]

8. Mattke, J.; Maier, C.; Reis, L.; Weitzel, T. Herd Behavior in Social Media: The Role of Facebook Likes, Strength of Ties, and Expertise. Inform. Manag. 2020, 57, 103370. [CrossRef]

9. Anand, K.S.; Aron, R. OGB on the Web: A Comparison of Price-Discovery Mechanisms. Manag. Sci. 2003, $49,1546-1562$. [CrossRef]

10. Chen, J.; Chen, X.; Song, X. Comparison of the OGB Auction and the Fixed Pricing Mechanism. Decis. Support Syst. 2007, 43, 445-459. [CrossRef]

11. Li, C.; Sycara, K.; Scheller-Wolf, A. Combinatorial Coalition Formation for Multiitem OGB with Heterogeneous Customers. Decis. Support Syst. 2010, 49, 1-13. [CrossRef]

12. Chen, Y.F.; Lu, H.F. We-Commerce: Exploring Factors Influencing Online Group-Buying Intention in Taiwan from a Conformity Perspective. Asian J. Soc. Psychol. 2015, 18, 62-75. [CrossRef]

13. Prentice, C.; Han, X.Y.; Hua, L.L.; Hu, L. The Influence of Identity-Driven Customer Engagement on Purchase Intention. J. Retail. Consum. Serv. 2019, 47, 339-347. [CrossRef]

14. Pappas, N. Marketing Strategies, Perceived Risks, and Consumer Trust in Online Buying Behaviour. J. Retail. Consum. Serv. 2016, 29, 92-103. [CrossRef]

15. Lim, W.M. An Equity Theory Perspective of OGB. J. Retail. Consum. Serv. 2020, 54, 101729. [CrossRef]

16. Liu, F.; Zhao, X.; Chau, P.Y.; Tang, Q. Roles of Perceived Value and Individual Differences in the Acceptance of Mobile Coupon Applications. Internet Res. 2015, 25, 471-495. [CrossRef]

17. Suki, N.M.; Suki, N.M. Determining Students' Behavioural Intention to Use Animation and Storytelling Applying the UTAUT Model: The Moderating Roles of Gender and Experience. Int. J. Manag. Educ. 2017, 15, 528-538. [CrossRef]

18. Chiang, C.Y.; Hsieh, C.H.; Ryan, H.C. The Study of Social Identification Effect of Reference Group on Individual Consumer's Internet Group Purchasing Strategy. Sun Yat-Sen Manag. Rev. 2016, 24, 77-114.

19. Liu, Y.; Sutanto, J. Buyers' Purchasing Time and Herd Behavior on Deal-of-the-Day Group-Buying Websites. Electron. Mark. 2012, 22, 83-93. [CrossRef]

20. Kukar-Kinney, M.; Xia, L. The Effectiveness of Number of Deals Purchased in Influencing Consumers Response to Daily Deal Promotions: A Cue Utilization Approach. J. Bus. Res. 2017, 79, 189-197. [CrossRef]

21. Klein, A.; Sharma, V.M. German Millennials' Decision-Making Styles and Their Intention to Participate in OGB. J. Internet Commer. 2018, 17, 383-417. [CrossRef]

22. Hung, S.W.; Cheng, M.J.; Hsieh, S.C. Consumers' Satisfaction with OGB an Incentive Strategy. Int. J. Retail Distrib. Manag. 2015, 43, 167-182. [CrossRef]

23. Rezaei, S. Segmenting Consumer Decision-Making Styles (CDMS) toward Marketing Practice: A Partial Least Squares (PLS) path Modeling Approach. J. Retail. Consum. Serv. 2015, 22, 1-15. [CrossRef]

24. Alavi, S.A.; Rezaei, S.; Valaei, N.; Ismail, W.K.W. Examining Shopping Mall Consumer Decision-Making Styles, Satisfaction and Purchase Intention. Int. Rev. Retail. Distrib. Consum. Res. 2016, 26, 272-303. [CrossRef]

25. Sharma, V.M.; Klein, A. Intention-to-Participate in OGB and Consumer Decision-Making Styles. Int. J. Electron. Market. Retail. 2016, 7, 245-271. [CrossRef]

26. Sharma, V.M.; Klein, A. Consumer Perceived Value, Involvement, Trust, Susceptibility to Interpersonal Influence, and Intention to Participate in OGB. J. Retail. Consum. Serv. 2020, 52, 101946. [CrossRef]

27. Tseng, S.-M.; Lee, M.-C. A Study on Information Disclosure, Trust, Reducing Search Cost, and Online Group-Buying Intention. J. Enterp. Inf. Manag. 2016, 29, 903-918. [CrossRef]

28. Tseng, S.-M.; Wu, C.-C. Understanding Moderating Effects of Involvement on Information Disclosure and Online Group-Buying Intention. Int. J. Innovat. Sci. Eng. Technol. 2017, 4, 293-301.

29. Klein, A.; Sharma, V. Consumer Decision-Making Styles, Involvement, and the Intention to Participate in OGB. J. Retail. Consum. Serv. 2022, 64, 102808. [CrossRef]

30. Dessart, L.; Veloutsou, C.; Morgan-Thomas, A. Consumer Engagement in Online Brand Communities: A Social Media Perspective. J. Prod. Brand Manag. 2015, 24, 28-42. [CrossRef]

31. Groupon. Groupon Investors. 2020. Available online: https://investor.groupon.com/home/default.aspx (accessed on 1 January 2022).

32. Chen, Y.F.; Shih, C.Y. The Pursuit of Fairness-Exploring Factors Influencing OGB Intention from the Perspective of Perceived. J. Inform. Manag. 2015, 22, 55-86.

33. Chen, Y.C.; Wu, J.H.; Peng, L.; Yeh, R.C. Consumer Benefit Creation in OGB: The Social Capital and Platform Synergy Effect and the Mediating Role of Participation. Electron. Commer. Res. Appl. 2015, 14, 499-513. [CrossRef]

34. Zeithaml, V.A.; Berry, L.L.; Parasuraman, A. The Behavioral Consequences of Service Quality. J. Mark. 1996, 60, 31-46. [CrossRef] 
35. Nayal, P.; Pandey, N. Digital Coupon Redemption: Conceptualization, Scale Development and Validation. Aust. J. Inform. Syst. 2020, 24, 1-23. [CrossRef]

36. Clark, R.A.; Zboja, J.J.; Goldsmith, R.E. Antecedents of Coupon Proneness: A Key Mediator of Coupon Redemption. J. Promot. Manag. 2013, 19, 188-210. [CrossRef]

37. Souiden, N.; Chaouali, W.; Baccouche, M. Consumers' Attitude and Adoption of Location-Based Coupons: The Case of the Retail Fast Food Sector. J. Retail. Consum. Serv. 2019, 47, 116-132. [CrossRef]

38. Ieva, M.; De Canio, F.; Ziliani, C. Daily Deal Shoppers: What Drives Social Couponing? J. Retail. Consum. Serv. 2018, 40, 299-303. [CrossRef]

39. Shiau, W.L.; Luo, M.M. Factors Affecting OGB Intention and Satisfaction: A Social Exchange Theory Perspective. Comput. Hum. Behav. 2012, 28, 2431-2444. [CrossRef]

40. Lim, W.; Ting, D.H. Consumer Acceptance and Continuance of OnlineOGB. J. Comput. Inform. Syst. 2014, 54, 87-96.

41. Pan, L.-Y.; Chiou, J.-S. How Much Can You Trust Online Information? Cues for Perceived Trustworthiness of Consumer-Generated Online Information. J. Interact. Mark. 2011, 25, 67-74. [CrossRef]

42. Das, G. Antecedents and Consequences of Trust: An E-Tail Branding Perspective. Int. J. Retail. Distrib. Manag. 2016, 44, 713-730. [CrossRef]

43. Lee, Y.-K.; Kim, S.Y.; Chung, N.; Ahn, K.; Lee, J.-W. When Social Media Met Commerce: A Model of Perceived Customer Value in Group-Buying. J. Serv. Market. 2016, 30, 398-410. [CrossRef]

44. Luo, M.M.; Chen, J.-S.; Ching, R.K.H.; Liu, C.-C. An Examination of the Effects of Virtual Experiental Marketing on Online Consumer Intentions and Loyalty. Serv. Ind. J. 2011, 31, 2163-2191. [CrossRef]

45. El Hedhli, K.; Zourrig, H.; Park, J. Image Transfer from Malls to Stores and Its Influence on Shopping Values and Mall Patronage: The Role of Self-Congruity. J. Retail. Consum. Serv. 2017, 39, 208-218. [CrossRef]

46. Kumar, A.; Paul, J. Mass Prestige Value and Competition between American versus Asian Laptop Brands in an Emerging Market-Theory and Evidence. Int. Bus. Rev. 2018, 27, 969-981. [CrossRef]

47. Rana, J.; Paul, J. Consumer Behavior and Purchase Intention for Organic Food: A Review and Research Agenda. J. Retail. Consum. Serv. 2017, 38, 157-165. [CrossRef]

48. Konuk, F.A. The Role of Store Image, Perceived Quality, Trust and Perceived Value in Predicting Consumers' Purchase Intentions towards Organic Private Label Food. J. Retail. Consum. Serv. 2018, 43, 304-310. [CrossRef]

49. Meesala, A.; Paul, J. Service Quality, Consumer Satisfaction and Loyalty in Hospitals: Thinking for the Future. J. Retail. Consum. Serv. 2018, 40, 261-269. [CrossRef]

50. Li, B.; Jiang, Y. Impacts of Returns Policy under Supplier Encroachment with Risk-Averse Retailer. J. Retail. Consum. Serv. 2019, 47, 104-115. [CrossRef]

51. Rahman, F.; Soesilo, P.K. The Effect of Information Exposure of Contract Manufacturing Practice on Consumers' Perceived Risk, Perceived Quality, and Intention to Purchase Private Label Brand. J. Retail. Consum. Serv. 2018, 42, 37-46. [CrossRef]

52. Adapa, D.; Cooksey, R. Factors Affecting Consumer's Continued Use of Internet Banking: Empirical Evidence from Australia. Aust. J. Inf. Syst. 2013, 18, 5-31. [CrossRef]

53. Asch, S.E. Effect of Group Pressure upon the Modification and Distortion of Judgments. J. Mark. Res. 1951, 16, 394-400.

54. Deutsch, M.; Gerard, H.B. A Study of Normative and Informational Social Influences upon Individual Judgment. J. Abnorm. Psychol. 1955, 51, 629-636. [CrossRef] [PubMed]

55. Suki, N.M.; Suki, N.M.; Mokhtar, A.H.A.; Ahmad, R. Assessing Normative and Informational Influences on Students' Opinion in Engaging Electronic Word of Mouth via Social Networking Sites. Proced. Econ. Financ. 2016, 37, 190-195. [CrossRef]

56. Bearden, W.O.; Netemeyer, R.G.; Teel, J.E. Measurement of Consumer Susceptibility to Interpersonal Influence. J. Consum. Res. 1989, 15, 473-481. [CrossRef]

57. Huang, K.W.; Department of Technology Management Chung Hua University, Hsinchu County, Taiwan. A Study of Initiator's Trust, Perceived Risk, Conformity Behavior, and Purchase Intention on Office OGB of Elementary School Teachers in Yilan County. A Thesis for the Degree Master of Business Administration Master Program. Unpublished work. 2019.

58. Huang, Y.C.; Management Sciences Department of Business Administration Asia University, Taichung County, Taiwan. The Effects of Relationship Marketing and Conformity upon Consumer Willingness to Make Online Group Purchases. A Thesis for the Degree Master of Business Administration Master Program. Unpublished work. 2017.

59. Gligor, D.; Bozkurt, S. FsQCA versus Regression: The Context of Customer Engagement. J. Retail. Consum. Serv. 2020, 52, 1-12. [CrossRef]

60. Van Doorn, J.; Lemon, K.N.; Mittal, V.; Nass, S.; Pick, D.; Pirner, P.; Verhoef, P.C. Customer Engagement Behavior: Theoretical Foundations and Research Directions. J. Serv. Res. 2010, 13, 253-266. [CrossRef]

61. Malthouse, E.C.; Calder, B.J. Comment: Engagement and Experiences: Comment on Brodie, Hollenbook, Juric, and Ilic. J. Serv. Res. 2011, 14, 277-279. [CrossRef]

62. Vivek, S.D.; Beatty, S.E.; Morgan, R.M. Customer Engagement: Exploring Customer Relationships beyond Purchase. J. Mark. Theory Pract. 2012, 20, 122-146. [CrossRef]

63. Pansari, A.; Kumar, V. Customer Engagement-The Construct, Antecedents and Consequences. J. Acad. Mark. Sci. 2017, 45, 294-311. [CrossRef] 
64. Brodie, R.; Hollebeek, L.D.; Ilic, A.; Juric, B. Customer Engagement: Conceptual Domain, Fundamental Propositions \& Implications for Research in Service Marketing (Lead Article; with Commentaries). J. Serv. Res. 2011, 14, 252-271.

65. Lee, S.Y.; Department of Business Administration National Kaohsiung University of Science and Technology, Kaohsiung County, Taiwan. The Influence of Corporate Image, Customer-Company Identification, and Customer Engagement on Repurchase Intentions-Taking Starbucks as an Example. A Thesis for the Degree Master of Business Administration Master Program. Unpublished work. 2020.

66. Ho, M.H.W.; Chung, H.F.L. Customer Engagement, Customer Equity and Repurchase Intention in Mobile Apps. J. Bus. Res. 2020, 121, 13-21. [CrossRef]

67. Huang, I.H.; Department of International Business Administration National Central University, Taoyuan County, Taiwan. Research on the Influence of Community Influencer Tracking Motivation on Consumer Behavior. A Thesis for the Degree Master of Business Administration Master Program. Unpublished work. 2020.

68. Bauer, R.A. Consumer Behavior as Risk-Taking. In Dynamic Marketing for A Changing World Hancock, 1st ed.; Hancock, R.S., Ed.; America Marketing Association: Chicago, IL, USA, 1960; pp. 389-398.

69. Cox, D.F. Risk Handling in Consumer Behavior-An Intensive Study of Two Cases. In Onald F. Cox, Risk Taking and Information Handling in Consumer Behavior; Harvard University Press: Boston, MA, USA, 1967; pp. 34-81.

70. Ting, K.C.; Tseng, S.R.; Pan, C.Y. The Study on the Perceived Risk of the Behavior of the Consumer in the Internet Shopping Mark. Rev. 2010, 7, 381-412.

71. Coltman, T.; Devinney, T.M.; Latukefu, A.; Migley, D.F. E-Business: Revolution, evolution, or Hype? Calif. Manag. Rev. 2001, 44, 57-89. [CrossRef]

72. Lin, C.L.; Department of Information Management National Central University, Taoyuan County, Taiwan. Exploring the Buying Attitude and Intention of Using Facebook Live Broadcast-the Platform Uses Clothing as an Example. A Thesis for the Degree Master of Business Administration Master Program. Unpublished work. 2018.

73. Glover, S.; Bendasat, I. A Comprehensive Model of Perceived Risk of E-Commerce Transactions. Int. J. Electron. Commer. 2010, 15, 47-78. [CrossRef]

74. Xu, B.; Lin, Z.; Shao, B. Factors Affecting Consumer Behaviors in Online Buy? It? Now Auctions. Internet Res. 2010, 20, 509-526. [CrossRef]

75. Hugstad, P.; Taylor, J.W.; Bruce, G.D. The Effects of Social Class and Perceived Risk on Consumer Information Search. J. Serv. Mark. 1987, 1, 47-52. [CrossRef]

76. Yang, K.; Kang, Z.; Chen, Z.; Sun, X.; Tang, W. Social Learning? Conformity? or Comparison?-An Empirical Study on the Impact of Peer Effects on Chinese Seniors' Intention to Purchase Travel Insurance. Tour. Manag. Perspect. 2021, $38,100809$.

77. Jahoda, M. Conformity and Independence: A Psychological Analysis. Hum. Relat. 1959, 12, 99-120. [CrossRef]

78. Huang, Y.; Shi, J.; Wang, L. Consumer Susceptibility to Interpersonal Influence in Mainland China. Asian J. Soc. Psychol. 2012, 15, 140-144. [CrossRef]

79. Lascu, D.; Zinkhan, G.M. Consumer Conformity: Review and Applications for Marketing Theory and Practice. J. Mark. Theory Pract. 1999, 7, 1-12. [CrossRef]

80. Kristia, K. Mediating Effect of Customer Engagement on the Relations between eWOM, Environmental Concern, and Intention to Purchase Second-Hand Clothing among College Students in Yogyakarta. J. Manaj. Bisnis 2021, 12, 162-175. [CrossRef]

81. Tsimonis, G.; Dimitriadis, S. Brand Strategies in Social Media. Mark. Intell. Plan. 2014, 32, 328-344. [CrossRef]

82. Silva, T.M. Building Relationships through Customer Engagement in Facebook Brand Pages. Mark. Intell. Plan. 2019, 38, 713-729. [CrossRef]

83. Mohammad, J.; Quoquab, F.; Mohamed Sadom, N.Z. Mindful Consumption of Second-Hand Clothing: The Role of eWOM, Attitude and Consumer Engagement. J. Fash. Mark. Manag. 2020, 25, 482-510. [CrossRef]

84. Lim, X.J.; Cheah, J.H. What S-Commerce Implies? Repurchase Intention and Its Antecedents. Mark. Intell. 2020, 38, 760-776. [CrossRef]

85. Thakur, R. Customer Engagement and Online Reviews. J. Retail. Consum. Serv. 2018, 41, 48-59. [CrossRef]

86. Sitkin, S.B.; Weingart, L.R. Determinants of Risky Decision-Making Behavior: A Test of the Mediating Role of Risk Perceptions and Propensity. Acad. Manag. J. 1995, 38, 1573-1592.

87. Jiang, G.; Zhang, M.; Cai, X.; Feng, X. Collaborative Governance in Shared Accommodation Platform: Moderating Role of Perceived Risk. J. Hosp. Tour. Res. 2021, 49, 112-128. [CrossRef]

88. Stone, R.N.; Gronhaug, K. Perceived Risk: Further Considerations for the Marketing Discipline. Eur. J. Market. 1993, 27, 39-50. [CrossRef]

89. Armstrong, J.S.; Overton, T.S. Estimating Nonresponse Bias in Mail Surveys. J. Mark. Res. 1977, 14, 396-402. [CrossRef]

90. Krishana, R.; Martin, X.; Noorderhaven, N. Why Does Trust Matter to Alliance Performance? Acad. Manag. J. 2006, 49, 894-917. [CrossRef]

91. Podsakoff Philip, M.; Dennis, W. OrganSelf-Reports in Organizational Research: Problems and Prospects. J. Manag. 1986, 12, 531-544

92. Bentler, P.; Chou, C. Practical Issues in Structural Modeling. Sociol. Method. Res. 1987, 16, 78-117. [CrossRef]

93. Fornell, C.; Larcker, D.F. Evaluating Structural Equation Models with Unobservable Variables and Measurement Error. J. Mark. Res. 1981, 18, 39-50. [CrossRef] 
94. Bagozzi, R.; Yi, Y. On the Evaluation of Structural Equation Models. J. Acad. Mark. Sci. 1988, 16, 74-94. [CrossRef]

95. Maruyama, G.M. Basics of Structural Equation Modeling; Sage Publications: Thousand Oaks, CA, USA, 1998.

96. Aiken, L.; West, S. Multiple Regression: Testing and Interpreting Interactions; Sage: Newbury Park, CA, USA, 1991.

97. Cohen, J.; Cohen, P. Applied Multiple Regression/Correlation Analysis for the Behavioral Sciences, 2nd ed.; Erlbaum: Hillsdale, NJ, USA, 1983.

98. Renko, M.M.; Carsrud, A.; Brännback, M. The Effect of a Market Orientation, Entrepreneurial Orientation and Technological Capability on Innovativeness: A Study of Young Biotechnology Ventures in the United States and in Scandinavia. J. Small Bus. Manag. 2009, 47, 331-369. [CrossRef]

99. Baron, R.M.; Kenny, D.A. The Moderator-Mediator Variable Distinction in Social Psychological Research: Conceptual, Strategic, and Statistical Considerations. J. Abnorm. Soc. Psychol. 1986, 51, 1173-1182. [CrossRef]

100. Rindfleisch, A.; Crockett, D.X. Cigarette Smoking and Perceived Risk: A Multidimensional Investigation. J. Public Policy Mark. 1999, 18, 159-171. [CrossRef]

101. Demir, D.; Yildiz, S.Y. The Mediating Role of Customer Engagement in the Effect of Social Media Marketing on Electronic Word-Mouth Intention. Bus. Manag. Stud. Int. J. 2021, 9, 649-661. [CrossRef]

102. Toor, A.; Husnain, M.; Hussain, T. The Impact of Social Network Marketing on Consumer Intention to Choose in Pakistan: Consumer Engagement as a Mediator. Asian J. Bus. Account. 2017, 10, 167-199.

103. Yeh, T.M.; Huang, K.I.; Huang, C.H. Let's Buy Together! The Antecedents of Group-Buying Intentions. Market. Rev. 2017, 14, 293-324.

104. Zhang, X.Z.; Management Sciences Department of Business Administration NanHua University, Chiayi County, Taiwan. A Study on the Relationships among Electronic Word of Mouth, Involvement, Perceived Risk and Purchase Intention of Online Shipping. A Thesis for the Degree Master of Business Administration Master Program. Unpublished work. 2018.

105. Booth, N.; Matic, J.A. Mapping and Leveraging Influencers in Social Media to Shape Corporate Brand Perceptions. Corp. Commun. Int. J. 2011, 16, 184-191. [CrossRef] 